J. Clin. Chem. Clin. Binchem.

Vol. 21, 1983, pp. 569-571

\title{
Characteristics of Proteinuria in Endemic Nephropathy
}

\author{
By Dubravka Čvoriščec \\ Institute for Clinical Laboratory Diagnostics, Clinical Hospital Centre Zagreb
}

\section{Radonić}

Department of Medicine, Medical Faculty University of Zagreb, Clinical Hospital Centre Zagreb

\section{S. Čeović}

Department of Epidemiology, Medical Centre Slavonski Brod and

\section{B. Aleraj}

Republic Institute for Health Protection of the Socialist Republic of-Croatia, Zagreb

(Received October 25. 1982/May 2. 1983)

Summary: Subjects living in the endemic area of Posavina round Slavonski Brod have a significantly greater incidence of proteinuria (13.6\%) than those living under the same conditions in the area where endemic nephropathy has not been observed $(5.5 \%)$. Following determination of the grade and type of proteinuria, physiologic proteinuria was.found in $36 \%$ of subjects from the endemic area. In nonphysiologic proteinuria the incidence of tubular proteinuria was $41 \%$. A slight selective glomerular proteinuria was found in $51 \%$, and other types of proteinuria in $8 \%$ of subjects. Tubular proteinuria was significantly higher in the endemic area than in the control area. The subjects with tubular proteinuria from the endemic area excrete significantly greater amounts of $\beta_{2}$-microglobulin and light immunoglobulin chains.

\section{Charakteristika der Proteinurie bei endemischer Nephropathie}

Zusammenfassung: Die Einwohner des endemischen Gebiets von Posavina (um Slavonski Brod) weisen eine signifikant größere Häufigkeit der Proteinurie $(13,6 \%)$, verglichen mit den Einwohnern, die unter denselben Lebensbedingungen im Gebiet leben, wo endemische Nephropathie nicht beobachtet wurde $(5,5 \%)$, auf. Bei der nichtphysiologischen Proteinurie lag die Häufigkeit der tubulären Proteinurie bei $41 \%$ der Untersuchten vor. Eine leicht ausgeprägte selektive glomeruläre Proteinurie wurde in $51 \%$ der Fälle beobachtet und andere Typen der Proteinurie bei den restlichen $8 \%$ dẹr Fälle. Der tubụläre Typ der Proteinurie war im endemischen Gebiet im Vergleich zu dem Kontrollgebiet erheblich erhöht.

Die Bewohner des endemischen Gebiets mit tubulärer Proteinurie scheiden erheblich größere Mengen von $\beta_{2}$-Mikroglobulin und von leichten Immunoglobulinketțen aus.

\section{Introduction}

Endemic nephropathy is a chronic disease of still insufficiently known aetiology. It has been recorded in some parts of Yugoslavia (the area of Posavina, west of Slavonski Brod, Podrinje, along the rivers Morava and Kolubara and in the border areas of Kosovo and Macedonia).

It has also been recorded in some parts of Bulgaria and Rumania (1). The investigations carried out so far suggest that endemic nephropathy is quite possi- 
bly a primary disease of the kidney tubules involving secondary reaction of the interstitial tissue. However, specific diagnostic methods, especially for the early stages of endemic nephropathy when proteinuria is still low are not available. The detection of tubular proteinuria in suspect patients and risk groups living in various endemic areas would be diagnostically useful (2).

The aim of this work was to establish the grade of proteinuria and recognize its characteristics in the population living in the area with proved endemic nephropathy. The data obtained were compared with those obtained in the investigation of the control rural area where no cases of endemic nephropathy have been registered.

\section{Materials and Methods}

The grade and type of proteinuria were investigated in 269 subjects of both sexes aged 17 to 78 years living in the area of endemic nephropathy (Kaniža and Bebrina). The examinees were selected after screening the total population by testing the first morning urine with sulphosalicylic acid. The positive proteinuria by the sulphosalicylic acid test was a criterion for inclusion in this study. For purposes of comparison, 25 inhabitants from the village Klakar, where no case of endemic nephropathy has been observed so far, were taken as controls.

The grade of protcinuria was determined with the biuret method (3) in the first morning urine. Protein separation was performed in all samples by electrophoresis on cellulose acetate membranes in $0.4 \mathrm{~mol} / \mathrm{l}$ tris-glycine buffer, $\mathrm{pH} 9.5$, ionic strength 0.03 , at $240 \mathrm{~V}$ for 3 hours, and 30 minutes (4). The separated proteins were identified after staining by comparison with an atlas of standard electrophoretograms. Special globulin fractions, which could not have been recognized by this procedure, were identified by urine immunoelectrophoresis using specific antisera to human free immunoglobulin light chains and antisera to human IgG fragments.

The type of proteinuria was determined by employing the following criteria:

1. Physiologic proteinuria:

2. Selective glomerular proteinuria:

3. Nonselective glomerular proteinuria:

4. Tubular proteinuria:

5. Mixed tubular-glomerular proteinuria:

\section{Results}

Results obtained in the investigation of the grade and type of proteinuria in the endemic area round Slavonski Brod and in the control area are presented in table 1 .

Tab. 1. Grade and type of proteinuria in the endemic nephropathy and control arca.

Endemic area Control area

(Urine protein concentration, $\mathrm{g} / \mathrm{l}$ )

\begin{tabular}{lll}
\hline Physiologic proteinuria & $0.01-0.19$ & $0.01-0.19$ \\
& $\overline{\mathrm{x}}=0.10$ & $\overline{\mathrm{X}}=0.11$ \\
& $\mathrm{~N}=96$ & $\mathrm{~N}=18$ \\
Tubular proteinuria & $0.20-2.27$ & $0.37-1.14$ \\
& $\overline{\mathrm{x}}=0.58$ & \\
$\mathrm{~N}=70$ & $\mathrm{~N}=3$ \\
Selective glomerular & $0.20-1.10$ & $0.20-0.43$ \\
proteinuria & $\overline{\mathrm{X}}=0.40$ & \\
& $\mathrm{~N}=90$ & $\mathrm{~N}=4$ \\
Nonselective glomerular & $0.55-4.55$ & - \\
proteinuria & $\mathrm{N}=6$ & \\
Mixed tubular glomerular & $0.83-2.44$ & - \\
proteinuria & $\mathrm{N}=7$ & \\
& & \\
\hline
\end{tabular}

Screening of the total population from this area with the sulphosalicylic acid test revealed proteinuria in 269 examinees $(13.6 \%)$. Following the quantitative determination of proteins with the biuret method, and determination of the type of proteinuria, physiologic proteinuria was found in 96 examinees (36\%), whereas one of the nonphysiologic types of proteinuria $(64 \%)$ was observed in the remaining 173 subjects.

Among nonphysiologic proteinurias, tubular proteinuria was observed in 70 examinees $(41 \%)$. The characteristics of the electrophoretogram in subjects with tubular proteinuria in the endemic area were: a normal or slightly increased albumin, and a pronounced $\beta_{2}$-microglobulin fraction. A diffuse protein fraction between $\beta$ - and $\gamma$-globulin was found in 25 urine specimens. Immunoelectrophoresis of these urine samples with specific antisera showed that light immunoglobulin chains were excreted in these subjects. Slightly pronounced selective glomerular proteinuria was observed in $90(52 \%)$ examinees. Only 6 examinees $(3.4 \%)$ from the endemic area revealed nonselective glomerular proteinuria, and there were only 7 subjects (4\%) with mixed proteinuria.

In contrast, in the control area (Klakar), proteinuria determined with the sulphosalicylic acid test was significantly lower $(5.5 \%)$. Physiologic proteinuria was observed in 18 examinees. Tubular proteinuria was observed in 3 persons, and selective glomerular proteinuria was found in only 4 subjects. 


\section{Discussion}

In previous work, we have already investigated the same populations for proteinuria, using the procedure of immunoelectrophoresis with complete antihuman sera. This work showd a greater incidence of tubular proteinuria $(2,5)$.

Similar results were obtained by Hall and coworkers (6) in the endemic area of Bosnia (Bjeljina). In contrast, Bruckner and coworkers (7) found a greater frequency of mixed proteinuria, but less tubular proteinuria in the endemic population in Rumania. Puchlev and coworkers (8) using electrophoresis of the urine with complete antihuman sera observed low molecular mass proteins, but also proteins of high molecular mass in their endemic area. Determination of the grade and type of proteinuria is certainly

\section{References}

1. Strahinjić. S. \& Stefanović, V. (1979) Proceedings of the 4th Symposium on Endemic (Balkan) Nephropathy. Niš, 1979. 7-15: 223-229.

2. Radonić, M., Radośević. Z.. Kcler-Baċoka, M., Mihelčić, N. \& Ceović. S. (1975) Lijec. Vjesn. 97, 547-555.

3. Savory, J.. Pu. P. H. \& Sunderman, F. M. (1968) Clin. Chem. 14. $1160-1170$

4. Alessandrino, L. (1972) Med. Lav. 63, 1-7.

5. Radośević. Z., Radonić, M.. Traeger, J., Manuel, Y., KelerBačoka, M. \& Čcović, S. Proceedings of the Second International Symposium on Endemic Nephropathy, Sofia, November 9-11, 1972. a valuable laboratory test in detecting and proving endemic nephropathy, on the assumption that the finding of tubular proteinuria is an early sign of the kidney response to a so far unknown agent of endemic nephropathy.

The fact that the proteins of low molecular mass, such as $\beta_{2}$-microglobulin, are found in subjects with a slightly pronounced proteinuria $(0.2 \mathrm{~g} / \mathrm{l})$ indicated that the procedure of electrophoresis of native urine on cellulose acetate membranes represents a sufficiently sensitive method. Likewise, traces of the fragments of immunoglobulin can be recognized with the same procedure. By immunoelectrophoresis they are further identified as light immunoglobulin chains. The clinical and epidemiological significance of this finding remains open.

6. Hall, P. W. \& Vasiljević, M. (1973) J. Lab. Clin. Med. 81. 897-904.

7. Stoica, Gh., Bruckner, I., Constantin. D. \& Michiu. V. (1969) Rev. Roum. Med. Int. 6, 323-330.

8. Puchlev, A., Dotchev, D., Dinev, I.. Dotcheva. Y. \& Ilicva, E. Proceedings of the Second International Symposium on Endemic Nephropathy, Sofia, November 9-11. 1972.

Mr. sc., dipl. ing. Dubravka Čvoriščcec Institute for Clinical Laboratory Diagnostics Clinical Hospital Center

Kišpatićeva 12 YU-4100 Zagreb 
。 